\title{
Публикации
}

\author{
УДК 329(470.5)"1905/1907”(045)
}

\section{В.С. Воронцов}

\section{ЛИСТОВКИ ПРИКАМСКОЙ И ПЕРМСКОЙ СОЦИАЛ-ДЕМОКРАТИЧЕСКИХ ОРГАНИЗАЦИЙ ПЕРИОДА ПЕРВОЙ РУССКОЙ РЕВОЛЮЦИИ 1905-1907 ГОДОВ}

\begin{abstract}
Представленная публикация включает вступительную статью и агитационные материалы периода первой русской революции, изданные Прикамской и Пермской социал-демократическими организациями. Публикуемые документы были найдены при разборе частного дома в Сарапуле и переданы на хранение в Удмуртский институт истории, языка и литературы УдмФИЦ УрО РАН. Находка включает 10 листовок и Летучий листок, изданные типографским способом, а также рукописные записи (отдельные страницы) с текстом о действиях рабочих в период вооружённого восстания против полиции и армейских подразделений. Листовки написаны доступным, доходчивым языком, с ярко выраженной направленностью на целевые группы (горожане-обыватели, рабочие, солдаты, новобранцы, учащаяся молодёжь). Они содержат информацию с разъяснениями действий правительства и революционеров, призывают к вооружённому восстанию, требуют созыва Всероссийского Учредительного собрания и бойкота выборов в Государственную Думу, рассказывают о значимых региональных событиях. Листовки региональных социал-демократических организаций являются важным источником для изучения истории первой русской революции 1905-1907 гг.
\end{abstract}

Ключевые слова: первая русская революция 1905-1907 гг., РСДРП, пермские и прикамские социал-демократы, агитационные материалы.

\section{DOI: $10.35634 / 2412-9534-2020-30-4-695-717$}

В истории партийной печати период первой русской революции 1905-1907 гг. занимает особое место. Очевидно, что во время подъёма общественного движения роль печати как мощного идеологического оружия особенно возрастает. Именно печать могла и выполняла функции коллективного пропагандиста, агитатора и организатора. Такие её виды, как газеты, листовки, прокламации, воззвания были способны оперативно реагировать на происходящие события, давать им оценку, разъяснять, ставить задачи, призывать к конкретным действиям и т. п. Более того, имелись технические возможности для быстрого издания и распространения подобной печатной продукции. Если за 5 предшествующих революции лет вышло 28 марксистских газет и журналов, то в годы первой русской революции - свыше 140 большевистских газет и журналов [3, с. 1], революционные организации выпустили около 10 тыс. листовок общим тиражом несколько млн. экз. [4, с. 6].

Изучение листовок имеет и теоретическое, и прикладное значение для исследования революционного процесса. В них отразились позиции революционных партий, а также непосредственные события общественно-политической жизни того периода (забастовки, стачки, демонстрации, вооружённые выступления и др.). В Советском Союзе публикация агитационно-пропагандистских материалов революционных партий началась уже в 1930-х гг., но наибольшую активность приобрела в 1950-е гг. [8-11]. Материалы революционной печати достаточно широко вовлекались в исследовательское поле советских историков $[1 ; 7 ; 16]$. Однако в 1990-е - начале 2000-х гг. интерес к этой теме уменьшился и активизировался только в 2010-е гг. [5]. На новом этапе развития российской историографии историки констатируют, что «историография политических партий России оказалась в кризисной ситуации. Перед исследователями вновь, как и много десятилетий назад, стоит задача: обратиться к первоисточникам» [23, с. 166]. Актуальность изучения и публикации документов партийной печати революционного периода возрастает и в связи с необходимостью пересмотра многих устоявшихся позиций применительно к «новой капиталистической реальности».

Представленная публикация включает листовки 1905-1906 гг., авторство которых принадлежит Прикамской группе (союзу) РСДРП и Пермскому комитету РСДРП, ареал влияния которых распространялся на Вятскую и Пермскую губернии, в том числе и на территорию, которая в 1920 г. вошла в состав Вотской (Удмуртской) автономной области. Коллекции и отдельные листовки этих региональных парторганизаций имеются на хранении в Государственном архиве Пермского края (ГА ПК. 
Ф. 160), в Государственном архиве Кировской области, в Центральном государственном архиве Удмуртской Республики (ЦГА УР. Ф. 216), в Центре документации новейшей истории Удмуртской Республики (ЦДНИ УР. Ф. 252), в Сарапульском историко-архитектурном и художественном музеезаповеднике; они в ограниченном количестве включались в публикации сборников документов [18; $19 ; 21]$, использовались при подготовке трудов по истории первой русской революции в Удмуртии [6; 14], а также истории революционной печати в регионе $[2 ; 12 ; 13 ; 15]$. Однако целенаправленной публикации данный комплекс листовок не подвергался.

Публикуемые документы были найдены в тайнике при разборе частного дома в Сарапуле и в феврале 2020 г. переданы в Удмуртский институт истории, языка и литературы УдмФИЦ УрО РАН ${ }^{1}$. Находка включает 10 листовок и Летучий листок, изданные типографским способом, а также рукописные записи (отдельные страницы) с текстом о действиях рабочих в период вооружённого восстания против полиции и армейских подразделений. Восемь листовок и летучий листок подписаны и изданы Пермским комитетом РСДРП, две - Прикамской группой РСДРП, авторство рукописного текста восстановить не удалось. Листовки датируются ориентировочно второй половиной ноября 1905 г. («К гражданам города Перми») — мартом 1906 г. («К учащейся молодёжи»).

Обнаруженные листовки различаются по размерам и формату: 22 на 35,5 cм (док. № 1-5), 25,5 на 35 cм (док. № 6), 19 на 29 см (док. № 7), 26 на 36 cм (док. № 8), 44 на 35 cм (док. № 9), 11,5 на 36 cм (док. № 10), 18,2 на 36 cм (док. № 11). Большая часть документов повреждена влагой и плесенью, местами текст неразборчив. Текст листовки Пермского комитета РСДРП «К годовщине великой российской революции» от 9 января 1906 г. (док. № 8) частично утрачен и приводится по имеющейся ранее публикации.

Листовки написаны доступным, доходчивым языком, с ярко выраженной направленностью на целевые группы: горожан-обывателей, рабочих, солдат, новобранцев, учащейся молодёжи.

По содержанию найденные материалы можно разделить на следующие группы: 1) листовки, посвящённые общероссийским политическим событиям, в том числе с разъяснениями действий правительства и революционеров, призывами к вооружённому восстанию, бойкоту выборов в Государственную Думу, требованием созыва Всероссийского Учредительного собрания (док. № 8-10); 2) листовки, обращённые к гражданам, рабочим, учащейся молодёжи, новобранцам и солдатам с призывом поддержать революционную борьбу пролетариата (док. № 1-4, 11); 3) листовки о значимых событиях в стране и регионе, в том числе о годовщине российской революции, забастовке на Воткинском заводе, гибели молодого революционера Якова Кузнецова в Перми (док. № 5-7).

Документы публикуются в соответствии с «Правилами публикации исторических документов в СССР» (М., 1990). Тексты документов воспроизведены по современным правилам правописания с сохранением стилистических особенностей подлинников. Документы расположены по хронологии. Датировка листовок, не имеющих даты, произведена в квадратных скобках с использованием слов «не ранее», «не позднее». Обоснование датировки приводится в подстрочных примечаниях. Восстановленные по смыслу слова взяты в квадратные скобки. Описание имеющихся печатей даётся после основного текста с указанием их расположения в подлиннике. Документы снабжены примечаниями по содержанию, которые расположены постранично.

Историческая справка. Пермский комитет РСДРП создан в июле 1902 г. на базе первой в Прикамье социал-демократической организации - пермской группы «Союза борьбы за освобождение рабочего класса», одним из основателей которой стал студент Петербургского университета Е. А. Пузырев ${ }^{2}$. К середине 1903 г. на Урале функционировало уже три социал-демократических ко-

\footnotetext{
${ }^{1}$ Документы переданы на хранение в архив УдмФИЦ УрО РАН первым секретарём Комитета Удмуртского республиканского отделения КПРФ В. П. Бодровым.

${ }^{2}$ Пузырев Евгений Александрович (1877-1900) родился в Перми в семье чиновника. Социал-демократ, один из основателей социал-демократической организации в Перми. Будучи студентом Петербургской военномедицинской академии, вступил в «Союз борьбы за освобождение рабочего класса». В 1898 г. за революционную деятельность арестован, исключён из академии и сослан в административном порядке под особый надзор полиции по месту жительства родителей - в Пермь. По воспоминаниям современников, Е. А. Пузырев оказал значительное влияние на пермскую революционную молодёжь. При его активном участии в 1898 г. в Перми оформилась социал-демократическая организация. Следуя примеру петербургского «Союза борьбы за освобождение рабочего класса», она приняла название «Пермская группа освобождения рабочего класса». Деятельность Е. А. Пузырева была прервана ранней смертью: 2 июня 1900 г. он скончался от туберкулёза.
} 
митета: Пермский, Средне-Уральский и Уфимский. К осени того же года создаётся первая социалдемократическая организация в Вятке, у истоков которой стояли отбывающие там наказание революционеры (Н. Н. Бушен ${ }^{1}$, Ф. А. Липкин ${ }^{2}$, Н. А. Шевелкин ${ }^{3}$ и др.). В условиях нарастающих в стране социально-экономических и политических противоречий и конфликтов влияние социал-демократов быстро распространяется на заводских рабочих и железнодорожников, студенческую и учащуюся молодёжь. Низовые социал-демократические группы и кружки организуются в ряде городов и в заводских посёлках.

Прикамская группа РСДРП была создана в 1903 г. под руководством Пермского и Среднеуральского партийных комитетов из разрозненных социал-демократических групп Елабуги, Осы, Сарапула. Одним из её организаторов стал В. А. Сухих ${ }^{4}$, активными участниками - А. М. Березин, П. А. Будрин, А. М. Коробейников, А. А. Ульянов, М. Зотов, В. Мышкин, Ал. и Ап. Федуловы. Уже накануне революционных событий 1905 г. социал-демократы Прикамской группы распространили своё влияние на всё южное Прикамье, включая Ижевский и Воткинский заводы [14, с. 22-32].

В первые месяцы революции Прикамская группа РСДРП, имевшая тесные связи с Пермским комитетом, развернула активную печатную пропаганду. К этому времени у неё была своя типография и гектографы. Только в первой половине 1905 г. было издано 25 тыс. листовок и прокламаций, в числе которых «Долой самодержавие!», «Да здравствует политическая свобода!», «К рабочим Воткинского завода» и др. [20, с. 25]. В 1906-1907 гг. Прикамская группа РСДРП издавала местную периодическую печать: «Известия прикамского рабочего», «Бюллетень» в Воткинске, «Рабочий листок» в Ижевске, участвовала в организации митингов и забастовок на Воткинском и Ижевском заводах, на предприятиях Сарапула, создании профессиональных союзов [2, с. 41; 21, с. 587-589]. В 1906 г. на второй партконференции (11 делегатов с решающим и 7 с совещательным голосом представляли 1200 рабочих) группа была переименована в Прикамский союз, принят свой устав, поставлена задача объединения социал-демократов всего Прикамья [22, л. 88-90].

Листовки региональных социал-демократических организаций являются важным источником для изучения истории первой русской революции. В них нашли отражение события общественнополитической жизни местного края в 1905-1907 гг., особенности протекания революционного процесса в регионе. Обнаружение комплекса подобных документов может стать импульсом для нового обращения к истории революционного движения в Удмуртии.

\footnotetext{
${ }^{1}$ Бушен Николай Н. (1873-1918) родился в Петербурге, воспитывался в приюте принца Ольденбургского. Учился в Рижском политехническом институте, за революционную деятельность выслан в Вятку, где организовал социал-демократический кружок при Мариинской вятской гимназии. В 1904 г. Н. Н. Бушен принимает участие в первой Уральской областной партийной конференции РСДРП. В период Революции 1905-1907 гг. активно работал в Пермском и Екатеринбургском комитетах РСДРП.

${ }^{2}$ Череванин (Липкин) Фёдор Андреевич (1868-1938) родился в г. Чериков Могилёвской губернии. Прослушал 5 семестров юридического факультета Петербургского университета, за участие в студенческих волнениях был исключён. Член РСДРП с 1900 г., меньшевик. Участник Революции 1905-1907 гг., делегат IV (1906) и V (1907) съездов РСДРП. Ф. А. Липкин пережил 5 арестов, ссылки в Вятку и Псков. Участник Лондонского съезда РСДРП 1907 г., член Предпарламента.

${ }^{3}$ Шевелкин Николай Алексеевич (1871-1969) родился в Москве. Революционный путь начал в 1897 г. во время учёбы в Рижском политехническом институте. Принимал активное участие в организации студенческих выступлений, создал подпольный социал-демократический кружок Риго-Орловской железной дороги. За участие в студенческой забастовке в 1899 г. Н. А. Шевелкина исключили из института и выслали из Риги. В период с декабря 1902 г. по ноябрь 2003 г. находился под гласным надзором полиции в Вятке. 26 ноября 1903 г. революционера сослали в Архангельскую губернию сроком на 5 лет.

${ }^{4}$ Сухих Василий Аркадьевич (1875-1954) родился в д. Дубровки Сарапульского уезда Вятской губернии в семье отставного солдата. Социал-демократ, один из организаторов Прикамской группы РСДРП. Определяющим фактором в формировании его взглядов стало революционное движение в стране в период экономического кризиса 1900-1903 гг. и знакомство с нелегальной социал-демократической литературой. По поручению комитета в августе 1904 г. приехал в Ижевск, где создал социал-демократический кружок. За участие в демонстрации 9 января 1906 г. был арестован, позднее осуждён и выслан в Сибирь.
} 


\title{
ДОКУМЕНТЫ
}

\author{
№ 1 \\ Листовка Пермской группы РСДРП «К гражданам города Перми» \\ с призывом поддержать бастующих рабочих
}

[Не ранее 15 ноября 1905 г. $]^{1}$

\author{
РОССИЙСКАЯ СОЦИАЛ-ДЕМОКРАТИЧЕСКАЯ РАБОЧАЯ ПАРТИЯ \\ Пролетарии всех стран, соединяйтесь!
}

\section{К ГРАЖДАНАМ ГОРОДА ПЕРМИ}

Мы призываем вас, граждане, поддержать рабочих, вступивших в борьбу за лучшую долю.

В Перми забастовали типографии, портные и модистки, почтово-телеграфные чиновники.

О забастовке почтово-телеграфных чиновников вам уже известно, что они хотели учредить Всероссийский почтово-телеграфный союз, но правительство нагло нарушило свое обещание о свободе союзов и прибегло к увольнению и аресту руководителей этого союза ${ }^{2}$.

Граждане. Поймите, что чиновники, ответившие правительству забастовкой на его насилие, борются и за Ваши права: сегодня запретили союз им, завтра запретят вам совещаться о ваших нуждах, защищать ваши интересы. Если чиновники одержат победу, вы воспользуетесь сладкими плодами. Дайте же им возможность одержать верх, поддержите их в трудную минуту борьбы.

Забастовавшие наборщики пермских типографий добиваются, чтобы была поднята расценка на их работы, чтобы было сокращено время труда, чтобы им была обеспечена врачебная помощь, отпуска для отдыха, чтобы расценки на работы устанавливались не капризами хозяина или заведующего, а по соглашению их с выборным от рабочих.

Вспомните, как тяжела работа наборщика, он целый день глотает вредную свинцовую пыль от букв, он нередко отравляется этой пылью, он слепнет от мелкой работы при тусклом свете лампы, он чахнет и преждевременно умирает.

Он умирает молодым, чтобы дать возможность вам, граждане, читать книги, газеты, афиши, а владельцам типографий [наживу] от продажи их вам. И борьба наборщиков с хозяевами сводится только к тому, чтобы добиться порядков, при которых будет лучше жить, при которых можно будет свободнее вздохнуть и не истощать себя работой для преждевременной смерти.

Хозяева типографий не хотят отступиться от своих барышей. Они упорно отказывают удовлетворить справедливые требования рабочих. Они грозят рассчитать их, выкинуть на улицу, обречь на голодную смерть, если они не согласятся стать на работу не только на прежних, а еще на худших условиях.

Для того чтобы помочь наборщикам сломить упорство хозяев, им нужна материальная поддержка и мы призываем всех пермских граждан оказать наборщикам эту поддержку.

Не менее нуждаются в материальной поддержке забастовавшие портные и модистки. Они забастовали тоже из-за того, что хозяева не хотят поступиться ни крошкой своих интересов. А между тем повышение расценок на работы, сокращение рабочего дня - вопрос жизни и смерти для рабочих. Их рабочее время тянется безобразно долго. Бывали случаи и даже у нас в Перми, что модистки-работницы перед большими праздниками зарабатывались до смерти, до потери сознания, до обмороков.

Но хозяев это ничуть не трогает: для них жизнь рабочего дешевле низменного интереса наживы, кармана мошны.

Ваша обязанность, граждане, прийти на помощь забастовавшим рабочим и работницам в мастерских мужского и женского платья. Они борются за лучшие условия жизни.

\footnotetext{
${ }^{1}$ Датируется по содержанию документа.

2 Забастовка почтово-телеграфных служащих продолжалась с 15 ноября по 10 декабря 1905 г. В начале декабря бастующие постепенно начали приступать к работе. Двадцать человек были арестованы. Оставшиеся на свободе члены Пермского комитета Всероссийского союза почтово-телеграфных служащих обратились за поддержкой к рабочим Мотовилихинского завода и в комитет профсоюза Пермской железной дороги. Представители железнодорожного союза и рабочих Мотовилихинского завода потребовали под угрозой забастовки освобождения арестованных. Убедившись в серьёзности этих угроз, власти вынуждены были освободить арестованных.
} 
В этом заинтересованы вы все, хотя бы потому, что лучшие условия труда предохранят рабочий класс от вырождения, от истощения, на почве которых развиваются в обществе болезни, угрожающие Вам и детям Вашим.

Поддержите же, граждане, забастовавших. Делайте взносы в стачечный фонд Пермского комитета Российской социал-демократической рабочей партии, стоящего во главе рабочего движения в Перми и руководящего борьбой рабочего класса. Содействуйте всеми способами увеличению этого стачечного фонда, имеющего целью материально поддержать забастовавших рабочих и дать им возможность победить в борьбе.

Русский пролетариат уже много сделал для России. На костях пролетариев, из крови их, пролитой на мостовую, вырастает политическая свобода, вырастает народная воля. Вы все вкусите сладких плодов этой свободы, добытой кровью боровшегося пролетариата.

Не оставайтесь же безучастными к его борьбе. Поддержите ее, содействуйте усилению руководящей борьбой пролетариата РСДРП, становитесь сами в ее ряды, привлекайте туда других, давайте ей возможность шире вести борьбу, доставляйте средства для этой борьбы и чем больше Вы это будете делать, тем ближе победа.

ПЕРМСКИЙ КОМИТЕТ РСДРП

Круглая печать (в левом верхнем углу): российская соц-демократическая рабочая партия, Пермский комитет.

№ 2

\section{Листовка Пермского комитета РСДРП «Письмо от Пермского комитета рабочим - социал-демократам и всему пермскому пролетариату» с призывом продолжить революционную борьбу}

[Не позднее января 1906 г. $]^{1}$

\section{РОССИЙСКАЯ СОЦИАЛ-ДЕМОКРАТИЧЕСКАЯ РАБОЧАЯ ПАРТИЯ}

Пролетарии всех стран, соединяйтесь!

\section{ПИСЬМО ОТ ПЕРМСКОГО КОМИТЕТА РАБОЧИМ - СОЦИАЛ-ДЕМОКРАТАМ И ВСЕМУ ПЕРМСКОМУ ПРОЛЕТАРИАТУ}

Товарищи. Не смущайтесь жестоких мер, принятых преступным правительством против рабочего класса и социал-демократической рабочей партии. Правительство, при помощи дикой казацкой шайки, озверелых жандармов и забитых солдат, может разгонять ваши собрания, вырывать из вашей среды наиболее стойких и сознательных товарищей, обезглавить вас, отнять от вас тех, кто руководил борьбой восставшего народа. Оно может это сделать, и оно это делает. Но победа будет за народом, а не за сворой псов и палачей. Вспомните, что было до той поры, когда революция дала нашей партии возможность выйти из подполья на приволье открытой работы. Мы, как мыши ютились по подпольям, по тайникам, по «конспиративным» квартирам. Там мы издавали свои листки и газеты, там мы соединяли рабочих в кружки, где они изучали экономическое и политическое положение своей родины, своего класса, там зарождалась наша рабочая партия, всегда отстаивавшая ваши интересы, всегда знакомившая вас с тем, как сделать, чтобы вам лучше, счастливее жилось. Нас искали, ловили, преследовали, прятали в остроги, избивали, рассылали по тундрам и болотам Сибири и севера. Нас было мало тогда, товарищи, и многим временами могло казаться, что совсем, окончательно, навсегда задушена социал-демократическая рабочая партия. Но она крепла, расширялась и углублялась. Она похожа была на тех сказочных витязей, которых раскололи пополам и половинки которых превратились каждая в нового витязя. Рать за ратью шла на встречу тюрьме, ссылкам, истязаниям. Партия, состоявшая из отдельных единиц, превратилась в партию, стоящую впереди могучей рати русского пролетариата, в партию, руководящую русским революционным рабочим классом.

\footnotetext{
${ }^{1}$ Датируется по содержанию документа.
} 
Когда революция усилилась настолько, что правительство стало бессильно бороться с ней, какие силы сразу развернула наша партия. Ее не только не смогли задушить, напротив, оказалось, что [она единственная] сильная политическая партия в России. Вот к каким [последствиям] привели гонения, аресты, преследования. [Поневоле вспоминаются слова] фарисея Гамалиила ${ }^{1}$, сказанные им еврейским [старцам] во время преследования христиан: «Оставьте. Если это дело человеческое, то оно погибнет само. А если дело Божье, то вам все равно ничего не поделать». Наше же дело - «дело Божье, потому что оно дело народное, а глас народа — глас Божий»... ${ }^{2}$ И преследования властей не только не помогают раздавить нас, но лишь умножают нашу партию...

Сколько раз во время арестов в Перми в 1903 и 1904 г. безмозглые жандармы ликовали и говорили: «Ну, от комитета осталась одна только грусть». Но стоило одолеть революции, как эта «грусть» развернулась в могучую партийную организацию, чуть не овладевшую властью в Перми и Мотовилихе.

Теперь вновь настал час гонений. Но не смущайтесь товарищи. Пусть часть борцов вырвана из вашей среды и томится в тюрьмах, другая скрылась в подполье. Мы вновь на время попрячемся по «конспиративным» квартирам, вновь начнем объединять рабочий класс в кружки, в «пятки» и «десятки» и вновь подготовим могучую рать рабочего пролетариата, которая стройно выйдет на новую битву с врагом, когда геройская борьба объединенного пролетариата Москвы и Петербурга обессилит правительство, вырвет у него, если не власть, то, по крайней мере, свободу союзов, собраний, слова, печати, стачек, неприкосновенность личности и жилища

Итак, товарищи, не падайте духом. У нас война народа, восставшего против правительства. На войне неизбежны убитые, раненые, пленные. У нас уже есть и те и другие. Пусть это не подорвет в вас убежденья в мощи восставшего народа. Он победит правительство, оставшееся без армии, без флота, без денег. Нам не нужны, ни армии, ни флоты, ни деньги.

\section{Сами набьем мы патроны, \\ К ружьям привинтим штыки .}

Если у вас есть возможность вести открытую борьбу - ведите. Если такой возможности теперь нет, - ведите тайную борьбу, как кроты, подтачивайте самые корни гнилого самодержавия. Пусть тьма еще ярится. Рассвет же недалек. Российской социал-демократической рабочей партии не истребить ни пулям солдат, ни нагайкам казаков, ни дурацким обязательным постановлениям обалдевших от революционной бури губернаторов, ни усиленным и всяким другим охранам.

«Оставьте», можно им сказать словами Гамалиила. А вы, товарищи, не бойтесь их преследований. Весь народ восстал и его ли могучей рати бояться «призрачной силы царей»?

С товарищеским приветом Пермский комитет РСДРП

В правом верхнем углу круглая печать ${ }^{4}$.

\section{№ 3}

Листовка Пермского комитета РСДРП «К солдатам о народном восстании» с призывом переходить на сторону восставшего народа

[Конеи 1905 2. $]^{5}$

РОССИЙСКАЯ СОЦИАЛ-ДЕМОКРАТИЧЕСКАЯ РАБОЧАЯ ПАРТИЯ

Пролетарии всех стран, соединяйтесь!

\section{К СОЛДАТАМ О НАРОДНОМ ВОССТАНИИ}

Солдаты. Восставший народ вступил в решительный бой с правительством. Народ требует, чтобы Россией правили не министры и чиновники, доведшие ее до разорения и банкротства, а выбор-

\footnotetext{
${ }^{1}$ Гамалиил — христианский святой, законоучитель, персонаж Нового Завета.

2 Здесь и далее отточие документа.

${ }^{3}$ Слова песни «Смело, товарищи, в ногу» (автор текста Л. Радин).

${ }^{4}$ Текст печати не читается.

5 Датируется по содержанию документа.
} 
ные представители, избранные всем народом. Правительство не хочет уступить народу, не хочет очистить теплых местечек, на которых ему было так привольно обирать народ, жать из него соки и набивать себе карманы. Оно выпустило законы, по которым намерено судить и карать за собрания, за союзы, за стачки. Оно снова хочет задавить народ, лишить его возможности и права сговариваться о своих нуждах, объединиться для защиты своих интересов и прав.

Солдаты. Народ, выведенный из терпенья, доведенный до крайности, восстал против правительства и вооруженной рукой взялся добыть себе права. Рабочие объявили всеобщую забастовку, чтобы заставить понять свою силу и сломить силу правительства. Забастовав, они вышли на улицы и на баррикадах бьются с правительственными войсками.

И войска переходят на сторону восставшего народа. Солдаты, которых долгие годы давили те же самые чиновники и министры, поняли, что им надо идти не с этими врагами народа, а вместе с восставшим народом, с тем народом, у которого одинаковый враг с солдатами, с тем народом, сыном которого является всякий солдат.

Вы, солдаты, дети народа, а не правительства. Всякий из вас или крестьянин-пахарь, или заводской рабочий. Как же вам, солдаты, вставать за правительство, за министров и чиновников и по их приказам стрелять в своего же брата-рабочего, в своего же отца-крестьянина? Нельзя вам забывать, что не вечно вы будете солдатами, что через несколько лет скинете вы солдатский мундир и шинель, расстанетесь с казармой и опять поступите на завод, на фабрику, опять вернетесь в деревню.

Что скажут вам тогда товарищи-рабочие, которых вы, солдаты, стреляли во время народного восстания? Как вы почувствуете себя, если вам встретятся в вашей деревне сироты и вдовы ваших же братьев, убитых солдатскими пулями... Проклятье и одно только проклятье будет уделом вашим, солдаты. Как Каины, убившие своего брата Авеля, будете вы скитаться среди людей...

Таков удел всякого врага народа и вам, солдаты, как сынам народа, нельзя ставать на защиту врагов от ваших восставших отцов и братьев.

В Перми, солдаты, тоже началось восстание народа. Быть может, недалек час, когда вас поведут против восставшего народа. Поэтому вам вперед надо сговориться, как действовать. Вам вперед надо решить не идти против своих братьев, вам надо отказаться стрелять в народ, отказаться защищать врагов народа от праведного гнева народа, восставшего за свои права, поступить так, как поступили те солдаты, которые расстреляли адмирала, приказавшего им стрелять в товарищей.

Итак, солдаты, соединяйтесь с восставшим народом и идите с народом, а не против народа.

ПЕРМСКИЙ КОМИТЕТ РСДРП

№ 4

Листовка Пермского комитета РСДРП «К новобранцам» о требованиях восставших

[Январь 1906 г.] ${ }^{1}$

\author{
РОССИЙСКАЯ СОЦИАЛ-ДЕМОКРАТИЧЕСКАЯ РАБОЧАЯ ПАРТИЯ \\ Пролетарии всех стран, соединяйтесь!
}

\title{
К НОВОБРАНЦАМ
}

Вас оторвали от родных семей, от родного крова, от фабричных станков и машин, от плуга и пашни. Вас оденут в солдатские мундиры, запрут на долгие годы в душные казармы и станут вас обучать солдатской науке. Вам скажут: «Отныне вы больше не рабочие и не крестьяне; вы солдаты, слуги царя и отечества». Вам скажут: «Царь и отечество едины суть, и защита царя есть защита отечества». Вам скажут: «Теперь идет война между правительством и «политиками»; «политики» - это шайка злоумышленников, которая хочет разорить Россию, привести ее к гибели; эта шайка подстрекает крестьян и рабочих, а те по своей слепоте их слушаются. Поэтому, дескать, по приказу начальства вы должны стрелять в «политиков», в рабочих и крестьян, женщин и детей». Под угрозой жестоких наказаний вас заставят присягать, что вы беспрекословно будете подчиняться воле начальства, хотя бы начальство приказывало идти против своих родных, отцов и братьев, хотя бы оно приказыва-

\footnotetext{
${ }^{1}$ Датируется по содержанию документа.
} 
ло вам поступать против своей совести. Когда вы проведете несколько месяцев в казарме, многие из вас быть может, забудут, что они вышли из среды рабочих и крестьян, многие будут думать, что они $\mathrm{TOЛЬКО}^{1}$ солдаты и больше ничего. Но теперь вы еще знаете, что это ложь, вы еще не успели оторваться от народа, вы еще чувствуете себя его детьми и вы должны теперь, уходя от него, вступая в ряды солдат решить, на чью сторону должны вы стать в происходящей теперь великой внутренней войне, войне между народом и правительством.

Вы знаете, что народ голоден и нищ; вы знаете, что народ закрепощен шайке чиновников. Бесконечный труд и убогий заработок - это удел рабочего; безземелье, разоренное хозяйство - это доля крестьянина. Крепостная зависимость от целой своры чиновников, начиная с городового и земского, кончая министром и царем - это доля всего русского народа. Царское правительство самодержавно правит странной; оно издает законы, по которым рабочим воспрещается бороться с хозяевами, а крестьяне должны слушаться своих помещиков; оно назначает подати, которые разоряют народ; оно собирает с народа ежегодно тысячи миллионов рублей, которыми распоряжается без ведома народа. Тяжело живется не только рабочим и крестьянам; тяжела также доля солдатская; он лишен свободы, так как без разрешения начальства не смеет отлучиться из казармы; назначенные правительством офицеры полные хозяева солдат и они досыта могут над ними глумиться и надругаться.

Против этих проклятых российских порядков борются русские рабочие и крестьяне, борются все сознательные люди, которых слуги правительства называют политиками. Чего же мы добиваемся?

Мы, требуем, чтобы каждый имел право говорить, о чем захочет, не боясь за это попасть в тюрьму, чтобы на газеты и книги, в которых говорится о народной нужде, начальство не накладывало запрета, чтобы собрания и союзы не разгонялись полицией, стачки не преследовались законом; следовательно, наши требования:

ВОСЬМИЧАСОВОЙ РАБОЧИЙ ДЕНЬ ПРОЛЕТАРИАТУ. ЗЕМЛЯ — КРЕСТЬЯНАМ. СВОБОДА И ВЫБОРНОЕ НАЧАЛЬСТВО ДЛЯ ВОЙСКА И ФЛОТА.

На эти требования царское правительство отвечает штыками и пулями, оно залило всю страну народной кровью, оно и вас заставит расстреливать рабочих и крестьян, обагрять свои руки братской кровью своего народа. Но если вы считаете себя сынами русского народа не слушайтесь жестоких приказов кровожадного правительства; когда народ поднимет знамя борьбы за свободу, переходите на его сторону, становитесь в его ряды, боритесь вместе с ним за общее дело.

ДОЛОЙ ПРЕСТУПНОЕ САМОДЕРЖАВИЕ

ДА ЗДРАВСТВУЕТ ВЕЛИКАЯ РОССИЙСКАЯ РЕВОЛЮЦИЯ

ПЕРМСКИЙ КОМИТЕТ РСДРП

\title{
№ 5
}

\section{Листовка Пермского комитета РСДРП «На смерть товарища Кузнецова»}

6 января 1906 г.

\author{
РОССИЙСКАЯ СОЦИАЛ-ДЕМОКРАТИЧЕСКАЯ РАБОЧАЯ ПАРТИЯ
}

\section{НА СМЕРТЬ ТОВАРИЩА КУЗНЕЦОВА}

В битве великой не сгибнуть бесследно

Павшие с честью во имя идей;

Их имена с нашей песней победной

Станут священны миллионам людей ${ }^{3}$.

\footnotetext{
1 Здесь и далее выделено в документе.

${ }^{2}$ Кузнецов Яков Софронович (1884-1906) - мотовилихинский рабочий, активный участник декабрьского вооружённого восстания 1905 г. в Мотовилихе, руководитель боевого «десятка». После подавления вооружённого выступления скрывался от властей, 3 января опознан полицейским и во время задержания тяжело ранен, по дороге в госпиталь скончался. В память о Я. С. Кузнецове в Мотовилихинском районе Перми названа улица.

${ }^{3}$ Слова песни «Варшавянка» (автор текста В. Свенцицкий, русский перевод Г. Кржижановского).
} 
Во вторник, 3 января, сворой палачей убит товарищ Яков Кузнецов член Пермского Комитета РСДРП. Товарищ Кузнецов ездил из Мотовилихи ${ }^{1}$ в город ${ }^{2}$, навстречу попалась орда полицейских и солдат. Кто-то из полицейских узнал героя мотовилихинских сражений и вздумал его задержать, но Кузнецов выскочил из саней и побежал, не желая сдаться живым своим смертельным врагам. Вся орда устроила настоящую охоту и бросилась в погоню за ним. С гиканьем и криком бежали полицейские и солдаты, непрерывно стреляя из револьверов. Отстреливаясь, товарищ Кузнецов спасался от опричнины и бежал вперед. Он взбежал на гору, побежал уже до ее середины и тут пал, пораженный солдатской пулей.

В детстве Кузнецов принимал очень деятельное участие в боях, которые в былое время часто устраивались мотовилихинской молодежью. Отличаясь ловкостью, силой и мужеством, он был избран этой молодежью атаманом. В 1904 г. он примкнул к социал-демократической партии и сразу стал очень деятельным членом мотовилихинской партийной организации. После июльской забастовки 1905 г. он принужден был скрываться, тщательно разыскиваемый жандармерией. После 17 октября, когда правительство, побежденное народом, начало готовиться к реакции и организовывать черные сотни, тов. Кузнецов принимал деятельное участие в милиции, в которой состоял десятником. Он отличился своим мужеством и распорядительностью в сражениях с казаками 13 декабря и когда (уже после этого сражения) был образован стрелковый отряд, он был назначен его начальником. Полиция знала тов. Кузнецова, боялась и смертельно ненавидела мужественного борца за свободу.

Он пал, как зверь, затравленный свирепыми стражами порядка, но дело, за которое он боролся, погибнуть не может. Мотовилихинский пролетариат запомнит имя своего славного товарища и будет продолжать до конца, до полной победы борьбу за то дело, которому принес уже столько жертв.

Вместе с поэтом мы скажем:

«Не нужно ни песен, ни слез мертвецам,

Воздайте им лучший почет,

Шагайте бесстрашно по мертвым телам,

Несите их знамя вперед» ${ }^{3}$.

Вечная память павшим в борьбе за свободу.

Проклятье убийцам.

ПЕРМСКИЙ КОМИТЕТ РСДРП комитет.

Круглая печать (вверху по центру): российская соц-демократическая рабочая партия, Пермский

№ 6

Летучий листок ${ }^{4}$ № 2 Пермского комитета РСДРП

РОССИЙСКАЯ СОЦИАЛ-ДЕМОКРАТИЧЕСКАЯ РАБОЧАЯ ПАРТИЯ

Пролетарии всех стран, соединяйтесь!

№ 2

7 января 1906 г.

Цена 2 коп.

\section{ЛЕТУЧИЙ ЛИСТОК \\ Пермского комитета}

\footnotetext{
${ }^{1}$ Мотовилиха исторически являлась промышленным районом, который развивался как заводской посёлок. В 1938 г. посёлок включён в территорию города Перми (Молотова) с образованием из него Мотовилихинского района.

${ }^{2}$ Город Пермь.

${ }^{3}$ Слова песни «Реквием» («Не плачьте над трупами павших борцов») (автор текста Л. Пальмин).

4 «Летучий Листок» - разновидность партийного издания, оперативно откликавшегося на актуальные темы. «Переходный» вариант от листовки к газете, в отдельные периоды становилось периодическим.
} 


\section{БОРЬБА РАБОЧИХ}

Главным средством борьбы, которым до последнего времени пользовался пролетариат, была всеобщая стачка. Богатства буржуазии и правительства, их дворцы и палаты, фабрики и заводы, одежда и питание, капитал и прибыль, - все это создается не белыми их ручками, а мозолистой рукой рабочего. «Все чем держатся их троны, дело рабочей руки», и когда эта рука отказывается им служить, это означает, что темному царству их приходит конец, что вся жизнь страны останавливается, как останавливается жизнь человека, когда прекращается биение его сердца.

Всеобщие забастовки внушают смертельный ужас правительству и буржуазии. Нагайки и пулеметы, лицемерно-милостивые речи и крохотные подачки, - все пускают они в ход, чтобы заставить рабочих снова стать на работу, снова создавать для них богатства.

Но пролетариат на штыки не уловишь и баснями не накормишь. Последний год был для нас, русских рабочих, полон непрерывной стачечной борьбы. Этой борьбой мы привели самодержавие к банкротству, и оно вынуждено было само признать свою негодность, неспособность управлять страной; оно несколько раз обещало народу различные реформы, было принуждено допустить свободные собрания и обещать конституцию, хотя и куцую. От прежней силы и могущества самодержавия, благодаря нашей борьбе, не осталось и следа, зато эта борьба, эти непрерывные забастовки увеличили, умножили наши ряды и разрозненные силы рабочих превратили в грозные своей сплоченностью батальоны.

Могущественным оружием рабочих является всеобщая забастовка; но на настоящее время мы пошли дальше, поднялись на высшую ступень. Пользуясь по-прежнему стачкой как средством борьбы, мы присоединяем к нему новое, еще более грозное средство - вооруженное восстание. Мы живем во время восстания, и каждый сознательный рабочий должен дать себе ясный ответ на вопрос: почему началось оно, кого должны мы винить за потоки пролитой крови? На этот вопрос правительство отвечает: виноваты крайние партии. То же самое говорят узколобые свободолюбцы из рядов буржуазии, говорят, так называемые, либеральные газеты, как например: «Уральский Край», «Всеобщая маленькая газета С.-Петербург» и др. Рабочие, дескать, и рады бы успокоиться, но соц.демократы захватили их в свои руки и заставляют бастовать, проливать свою кровь, сражаться за свободу.

В самом деле: кто закрывает рабочие газеты, кто разгоняет народные собрания? Кто расстреливает безоружных, кто организует черные сотни? Все это дело рук правительства, того самого правительства, которое издало манифест 17-го октября, которое обещало свободу печати и собраний и неприкосновенность личности. Правительство решило отнять у народа ту небольшую свободу, которую он завоевал в октябре, и пролетариат вынужден подняться для защиты своих завоеваний. Правительство вызвало новый взрыв борьбы, но теперь мы уже не можем ограничиться забастовкой, мы переходим к борьбе с оружием в руках. Мы старались, вспомните это, в предыдущих забастовках ограничиться мирной борьбой, но правительство всегда превращало их в бойни беззащитных, безоружных людей. Против мирной забастовки правительство пускает в ход нагайки и штыки. Своими зверствами оно как бы хочет сказать нам: «Если вы хотите бастовать, вооружайтесь!» Мы принимаем вызов правительства, и мы будем бастовать, мы будем вооружаться, мы будем бороться до полной победы.

Какая разница между началом и концом только что ушедшего в вечность 1905 года, первого года Великой Российской Революции! Этот год начался вооруженным нападением правительства на безоружный петербургский пролетариат (9 января), а закончился вооруженным восстанием, нападением пролетариата на одряхлевшее самодержавие. Декабрьские дни ознаменовались двухнедельным сражением в Москве, восстанием в Прибалтийском крае, сражениями в Ростове-на-Дону и вокруг Бахмута, стычками по всей Руси, в том числе Сормово и Мотовилихе.

Вооруженное восстание началось и недалеко уже время, когда под ударами «мускулистой руки» миллионов рабочего люда огражденное штыками самодержавие разлетится в прах.

Борьба еще не закончилась, впереди новые битвы, -

«На бой кровавый, святой и правый.

Марш, марш вперед, рабочий народ!» ${ }^{1}$

(Продолжение следует)

\footnotetext{
${ }^{1}$ Слова песни «Варшавянка» (автор текста В. Свенцицкий, русский перевод Г. Кржижановского).
} 


\title{
ПИСЬМА С ЗАВОДОВ ВОТКИНСК
}

3 декабря мастеровые цехов паровозного, механического, котельного, чугунно-литейного и кузнечного забастовали, поддерживая требования чернорабочих. После того, как все бросили работы, мастеровые, собравшись против башни около трех с половиной тысяч человек, приступили к выбору из своей среды в Совет рабочих, который бы руководил всей стачкой. Выборные, совместно с депутатами цехов, образовали Совет рабочих депутатов, который, распустив массу, отправился в заводской театр для обсуждения текущих дел. Тотчас же было решено закрыть винные и пивные лавки, о чем известили полицию, которая немедленно привела в исполнение это приказание. [Пот]ом вызван был смотритель завода, [ему] было приказано распорядиться в п[роп]уске выходящих с завода ${ }^{1}$.

Затем приступлено было к другим вопросам, а именно: как поступить с теми цехами, которые не примкнут? Когда этот вопрос решался, то пришли выборные от цехов: железнодорожного, сталелитейного, столярного и раб[очих] электрической станции спросить, как им поступить? Совет рабочих депутатов велел им забастовать, кроме железнодорожного, который в это время подвозил дрова для завода. Была выбрана депутация к начальнику с требованием об увеличении платы для чернорабочих, начальник сказал им, что он не может своей властью прибавить, выходя из нормы, данной главным начальником, пошлите телеграмму и просите его; рабочие согласились ждать ответа, не приступая к работам. В этом же собрании была организована местная милиция, которая по ночам делала обходы. После этого собрание было распущено.

На другой день был митинг; его провели хорошо. На 4-й день на митинге уже было решено подать телеграмму, что мы, рабочие, требуем Учредительного Собрания и освобождения нашего товарища Мышкина. На 6-ой день стачки Сов[ет] раб[очих] деп[утатов] решил прекратить забастовку, для чего послал депутацию к начальнику завода. Забастовка была прекращена, ввиду предстоящей всеобщей российской забастовки.

Эта забастовка показала, что полиция [и] начальство стало считаться с Сов[етом] раб[очих] депутатов, что видно из следующего: на отказ начальника исполнить требование рабочих (не удерживать долгов в кассу горнозаводского товарищества) рабочие ответили обещанием снять милицию, и начальник уступил.

\section{«ПЕРЕСТРЕЛКА С ЖАНДАРМАМИ В ЧУСОВОЙ» ${ }^{2}$}

\section{№ 7}

\section{Листовка Пермского комитета РСДРП «К годовщине Великой Российской революции»}

9 января 1906 г.

\author{
РОССИЙСКАЯ СОЦИАЛ-ДЕМОКРАТИЧЕСКАЯ РАБОЧАЯ ПАРТИЯ \\ Пролетарии всех стран, соединяйтесь!
}

\section{К ГОДОВЩИНЕ ВЕЛИКОЙ РОССИЙСКОЙ РЕВОЛЮЦИИ}

9 ЯНВАРЯ

Голод и нужда, нищенский заработок, бесконечный труд да полицейский разгул - все это издавна было уделом русского рабочего. Все это он сносил безропотно и кротко, и немногочисленны были ряды сознательных борцов за лучшую долю, за волю и счастье народа. Царское правительство свирепо душило свободную мысль, тюрьма да Сибирь были наградой тем, кто будил спящих, пробуждал сознание темных масс, тем, кто «свободу, как мать дорогую, любил и во имя ее подвизался».

\footnotetext{
${ }^{1}$ Забастовка на Воткинском заводе проходила с 3 по 7 декабря 1905 г. под руководством Совета рабочих депутатов (председатель - рабочий П. А. Чубуков).

${ }^{2}$ Текст второй страницы отсутствует.

${ }^{3}$ В сборнике документов «Революция 1905-1907 гг. в России. Документы и материалы. Второй период революции. Январь - апрель 1906 года. Кн. 1» (М., 1957) название воспроизведено с ошибкой: «К годовщине великой октябрьской революции - 9 января» (с. 775).
} 
Мучительно медленно и мрачно проходили года за годами; царское правительство ни в чем, ни от кого не встречало удержу, и все туже и туже затягивало оно петлю на шее народа.

9 января прошлого года петербургский пролетариат понес к царю свои страдания, свои нужды и заботы. Петербургский пролетариат хотел просить царя, чтобы снял он оковы рабства со своего народа, чтобы созвал народных представителей для уничтожения старых порядков на Руси, для избавления ее от своры чиновников, чтобы даровал он свободу собраний и союзов, чтобы прекратил губительную войну, которую правительство еще не успело тогда покончить позорным миром; и о многом еще хотел он просить царя.

И сотни тысяч петербургских рабочих пошли к нему с иконами и хоругвями, с детской, наивной верой что [царь] примет и выслушает их, что царь не знает народного горя, которое тщательно скрывается от него министрами, но когда узнает, то непременно удовлетворит все просьбы народа.

И царь встретил народ и ответил на просьбы его по-царски. Тысячами жизней заплатил петербургский пролетариат за свою наивную веру. Царское правительство совершило вооруженное нападение на безоружных рабочих и победило их, но этой победой, но этой победой оно подрыло то основание, на котором стояло; эта победа царя над народом уничтожила веру народа в царя, единственную силу, которая может поддержать трон; теперь этой силы - темноты народных масс - у царя уже нет, теперь его власть опирается только на штыки, и поэтому теперь вся России представляет театр войны, в которой правительство и остатки верных ему по своей слепоте войск находятся в одном лагере, весь народ - в другом.

Сегодня годовщина великой внутренней войны революционного народа с его поработителями. Оглянемся на этот год. Мы вступили в войну безоружные, разрозненные, правительство вступило в нее во всеоружии власти и могущества; у нас была только жгучая ненависть к тиранам да голые руки; у правительства были нагайки, пулеметы, тюрьмы да виселицы. Но у нас было сознание правоты нашего дела, мы начали войну, полные уверенности в победе.

Год революции! Как выросли наши силы: рабочие поднимаются повсеместно; в самых глухих углах крестьяне присоединяются к нам; присоединяются к нам различные слои общества, до сих пор стоявшие в стороне от революционного движения, как, например, почтово-телеграфные служащие; матросы перешли на сторону народа и сражаются в первых рядах революции; солдаты постепенно переходят на сторону народа, и в Москве правительство заперло пехоту в Кремль, боясь, что она встанет в ряды революции, а в Сибири кое-где даже казаки изменили самодержавию и присоединились к рабочим. Передовой отряд всей этой громадной революционной армии — пролетариат сплачивается в грозные батальоны, вооружается и поднимает знамя вооруженного восстания.

Год революции! Куда девались сила и могущество самодержавия? Оно потеряло флот, перешедший на сторону революции, оно уже не надеется на войска, переставшие быть опорой тиранов и все чаще и чаще отказывающиеся стрелять в своих братьев, оно находится на краю банкротства, так как доведя народ до обнищания, оно не может уже вытягивать из него податей, а банкиры, у которых оно одалживало в былое время сотни миллионов рублей, теперь не желают уже рисковать своей мошной. Бессильное справиться с революцией, самодержавие пытается ее обмануть, оно говорит о реформах, о свободах, о конституции и народных представителях, но тупое и бессмысленное, оно может только дарить верноподданным манифесты и не может провести в жизнь ни одной, даже маленькой реформы. Правительство чует свою неизбежную гибель; перед смертью оно хочет насладиться, упиться народной кровью, и оно проливает потоки этой крови. Это — предсмертные корчи издыхающего чудовища. В потоках крови оно потонет.

Товарищи! Объединяйтесь и сплачивайтесь под знаменем революционной социал-демократии для решительной борьбы; чем сильнее мы сплотимся, чем решительнее будет наша борьба, тем скорее наступит день, когда мы:

«Свергнем могучей рукою

Гнет роковой навсегда.

И водрузим над землею

Светлое царство труда» ${ }^{1}$.

\footnotetext{
${ }^{1}$ Слова песни «Смело, товарищи, в ногу» (автор текста Л. Радин).
} 
Листовки Прикамской и Пермской социал-демократических организаций...

707

СЕРИЯ ИСТОРИЯ И ФИЛОЛОГИЯ

2020. Т. 30, вып. 4

Долой преступное самодержавие!

Да здравствует всенародное вооруженное восстание!

Да здравствует всенародное Учредительное собрание!

ПЕРМСКИЙ КОМИТЕТ РСДРП

Круглая печать: Российская соц-демократическая рабочая партия, Пермский комитет.

Печатается по: Револючия 1905-1907 г2. в России. Документы и материалы. Второй период революичи. Январь - апрель 1906 года. Кн. 1. М.: Издательство Академии наук СССР, 1957. С. 775-777.

№ 8

Листовка Пермского комитета РСДРП к рабочим с призывом бойкотировать выборы

в Государственную Думу и продолжить революционную борьбу за Демократическую республику и Всенародное Учредительное Собрание

6 февраля 1906 г.

\section{РОССИЙСКАЯ СОЦИАЛ-ДЕМОКРАТИЧЕСКАЯ РАБОЧАЯ ПАРТИЯ}

Пролетарии всех стран, соединяйтесь!

Товарищи! Уже более года прошло с тех пор, как широкие массы рабочего класса вышли открыто на борьбу с произволом и насилием царского самодержавия. Более года за рабочим классом поднялся и весь русский народ. Более года правительство расстреливает народ. Более года льются по городам и деревням потоки народной крови, а борьба все разгорается. Каждое новое насилие вызывает еще более сильную ненависть в самых широких слоях народа.

Более года правительство зажато в тисках и наряду с расстрелами оно пытается лживыми обещаниями мелких уступок обмануть народ и сохранить за собой господство.

Еще 12 Декабря 1904 года вышел царский указ о различных «реформах» и «улучшениях». А в январе 1905 г. были расстреляны тысячи мирных безоружных рабочих. На эти убийства пролетариат ответил всеобщей политической забастовкой во многих городах. Вскоре после забастовки - 18 Февраля последовало обещание созвать «народных представителей». Повсюду сидели чиновники, трудились и разрабатывали закон о «народном представительстве». Появился закон 6 авг.[уста]. По этому закону весь рабочий класс, городская и деревенская беднота, все мужчины и женщины, не достигшие 25 лет, оставались за дверями Государственной Думы. - Пролетариат на эту новую попытку самодержавия обманутых [так в тексте] ответил — «Долой Госудаств.[енную] Думу!» Правительство подготовляло выбора, а пока, по-прежнему в стране царил произвол и насилие, по-прежнему, избивались сотни, тысячи рабочих и голодных крестьян.

Всеобщая забастовка в октябре заставила правительство издать манифест 17 октября, с обещанием свободы собраний, союзов, неприкосновенности личности и жилища, но и эти обещания остались на бумаге. По-прежнему самодержавное правительство хозяйничало в стране и подавляло добытые пролетариатом свободы. С еще большей жестокостью [боролось] правительство с народом. В манифесте было дано торжественное обещание, «что отныне ни один закон не получит силу действия без утверждения народными представителями» и в тоже время чиновники издают временные правила уничтожившие все обещанное в манифесте 7 дек.[абря]; по всей России начинается новая политическая забастовка, пролетариат во многих городах выходил с оружием в руках. Вся Россия превращается в военный лагерь. Под грохот пушек в Москве, Екатеринославле, Нижнем и друг.[их] г.[ородах] появляется новый царский указ, новая попытка «успокоить» страну фальшивым предоставлением гражданских прав. Чем же разнится закон 11 дек.[абря] от закона 6 авг.[уста]? Основы избирательного закона сохраняются: тот-же 25 л[етний] возраст для избирателей, отнимающий право у молодых, наиболее энергичных граждан; те же перегородки между отдельными группами избирателей; та же многостепенность выборов; то же лишение женщин избирательного права; то же отсутствие предвыборной агитации и предвыборных и избирательных собраний и при всем этом имущест- 
венный ценз сохраняет свою силу к «цензовикам» ${ }^{1}$ лишь прибавляются новые разряды избирателей. Таким образом и по закону 11 дек.[абря] выборы не всеобщие, не равные, не прямые и не тайные. В чем же улучшение?

Мелкая буржуазия, все чиновники, представители так называемой интеллигенции, занимающие самостоятельно квартиры, получают избирательное право в крупных городах двухстепенное, а в уездных и мелких трехстепенное.

Для крестьян все изменение заключается в том, что выборы формально сделаны четырехстепенными. «Домохозяева» могут теперь избирать новый состав волостных сходов из представителей каждых 10 дворов.

Фактически же все осталось по старому: деревенская беднота не может заметно повлиять на исход выборов; деревенские же богатеи пользуются всеми выгодами своего положения.

Рабочим тоже дано избирательное право, они только так же будут выбирать, но выборные от них дальше губернского избирательного собрания не попадут. Довольно с них и этой чести. С «господами» рядом посидят и достаточно, чего им еще надо.

Те, - которые ценою собственной крови, ценою долгой упорной борьбы добивались полной свободы, добивались Всенародного Учредительного Собрания, добивались демократической республики, - приглашаются правительством к выборам. Правительство с ног до головы забрызганное кровью перебитых им рабочих приглашает выборных от рабочих же посидеть рядом с «господами». Право выбирать по 1-одному от каждой 1000 - получают рабочие, проработавшие не менее 6 месяцев в заведении, занимающем более 50 рабочих* (т. е. 20 подобных мастерских могут выбрать одного).

Таким образом, миллионы, работающие в мелких предприятиях, выбрасываются за борт, если у них нет «самостоятельных» квартир. Устраняются от выборов и рабочие, проработавшие в данном заведении менее 6 мес.[яцев]. А много ли рабочих за последний год беспрерывных забастовок сохранило свои места в течении 6 мес.[яцев]? Ясно, что может быть одна четвертая часть рабочего класса получит право выбирать уполномоченных. Уполномоченные выбирают выборщиков, которые участвуют в общих городских и губернских собраниях, где избираются уже гласные думы. Следовательно для рабочих выбора установлены трехстепенные. При этом рабочие могут выбирать из рабочих своей фабрики и выборщиков только из среды уполномоченных, точно также, как крестьяне выбирают только крестьян. В губернских избирательных собраниях рабочие будут по сравнению с другими избирателями в ничтожном количестве. Только в Москве их будет одна восьмая часть, а в Питере - одна десятая, что же касается других городов, они будут представлять лишь одну двадцатую - двадцать пятую часть всех избирателей. Следовательно провести своего депутата в Думу им не удастся и придется им остаться без представителя или подать голос за какого-нибудь буржуазного представителя.

Свободы предвыборных собраний и предвыборной агитации нет, «посторонние» на собрания избирателей, уполномоченных и выборщиков не допускаются. За этим будет следить всякое начальство, полиция и т. д., которые будут присутствовать на предвыборных и избирательных собраниях.

Товарищи рабочие, как же должны ответить вы на это издевательство над вашими требованиями? В течение целого года по всей России пролетарии ведут борьбу за власть народа и полные гражданские права. По всей России правительство расстреливает без счета рабочих и крестьян, вводит военное положение, учреждает усиленные и чрезвычайные охраны, не дает возможности таким образом собраться и столковаться - а вы выбираете! Варварское правительство поставит «для порядка» на всех предвыборных собраниях полицию и казаков, а вы под охраной штыков и нагаек выбираете!

Наглое царское правительство выкидывает большую часть рабочего класса за борт выборов а вы выбираете! Забрызганные вчера народной кровью чиновники сегодня насмехаются над вами - a вы выбираете!

Нет не должен никто участвовать в этой подлой, гнусной комедии. Никто, кому дороги интересы народа не должен участвовать в выборах. Комедия 11 дек.[абря] должна также провалиться, как и комедия 6 августа. Пролетариат России достаточно вырос, чтобы понять, что ждать чего-либо хорошего от своих убийц он не должен. Он должен осознать, что лишь воздвигнутое на развалинах царского самодержавия временное революционное правительство созовет действительно народных представителей, созовет учредительное Собрание на основании всеобщей, равной, прямой и тайной подачи голосов. По прежнему пролетариат должен строиться в грозные боевые колонны под знаме-

\footnotetext{
${ }^{1}$ Лицо, обладающее имущественным цензом.
} 
нем Рос.[сийской] Соц.[иал]-Д.[емократической] Раб.[очей] Пар.[тии], по прежнему готовиться к последнему окончательному сражению жертвой которого должно стать окровавленное царское самодержавие. Рабочий класс должен отбросить от себя фальшивую подачку. Как и прежде на этот новый вызов правительства, он должен ответить грозным криком: Долой Государственную Думу! Долой народных убийц! Да здравствует Всенародное Учредительное Собрание! Да здравствует Демократическая республика! Да здравствует социализм! Да здравствует Р.С.-Д.Р.П.!»

\title{
ПЕРМСКИЙ КОМИТЕТ Р.С.-Д.Р.П.
}

Круглая печать (внизу в правом углу): российская соц-демократическая рабочая партия, Пермский комитет.

\section{№ 9}

Листовка Пермского комитета РСДРП «Победы пролетариата и "уступки" правительства»

[не ранее декабря 1905 2. $]^{1}$

\author{
РОССИЙСКАЯ СОЦИАЛ-ДЕМОКРАТИЧЕСКАЯ РАБОЧАЯ ПАРТИЯ \\ Пролетарии всех стран, соединяйтесь!
}

ПОБЕДЫ ПРОЛЕТАРИАТА И «УСТУПКИ» ПРАВИТЕЛЬСТВА

\begin{tabular}{|c|c|c|}
\hline $\begin{array}{l}\text { ЧТО САМ ВЗЯЛ СЕБЕ РУС- } \\
\text { СКИЙ ПРОЛЕТАРИАТ }\end{array}$ & $\begin{array}{l}\text { ЧТО В МАНИФЕСТЕ } 17 \text { ОК- } \\
\text { ТЯБРЯ ВЫНУЖДЕНО БЫЛО } \\
\text { ТОРЖЕСТВЕННО И ВСЕНА- } \\
\text { РОДНО ОБЕ-ЩАТЬ ПРАВИ- } \\
\text { ТЕЛЬСТ-ВО, ОБЪЯТОЕ } \\
\text { СТРАХОМ ПРЕД ПОБЕДАМИ } \\
\text { ПРО-ЛЕТАРИАТА? }\end{array}$ & $\begin{array}{l}\text { КАК ВЫПОЛНИЛО ПРА- } \\
\text { ВИТЕЛЬСТВО ДАННЫЕ ИМ } \\
\text { ОБЕЩАНИЯ? }\end{array}$ \\
\hline $\begin{array}{l}\text { 1) СВОБОДУ СОБРАНИЙ. Он } \\
\text { без всякого разрешения началь- } \\
\text { ства сходился на митинги гро- } \\
\text { мадными толпами в несколько } \\
\text { десятков тысяч. }\end{array}$ & $\begin{array}{l}\text { 1) СВОБОДУ СОБРАНИЙ, уже } \\
\text { добытую геройской борьбой } \\
\text { пролетариатом }\end{array}$ & $\begin{array}{l}\text { 1) СВОБОДУ СОБРАНИЙ оно } \\
\text { подчинило закону, по которому } \\
\text { о собраниях надо заявлять поли- } \\
\text { ции за } 3 \text { дня. Присутствовать на } \\
\text { собрании нельзя ни учащимся, } \\
\text { ни солдатам, ни вооруженным. } \\
\text { Отклоняться от дозволенной } \\
\text { программы нельзя. За наруше- } \\
\text { ние обещан арест до трех меся- } \\
\text { цев. }\end{array}$ \\
\hline $\begin{array}{l}\text { 2) СВОБОДУ СЛОВА на собра- } \\
\text { ниях, не подлежащих никакому } \\
\text { надзору и контролю полиции. На } \\
\text { них говорилось обо всем вплоть } \\
\text { до вооруженного восстания про- } \\
\text { тив правительства. }\end{array}$ & $\begin{array}{l}\text { 2) СВОБОДУ СЛОВА, уже до- } \\
\text { бытую геройской борьбой про- } \\
\text { летариата. }\end{array}$ & $\begin{array}{l}\text { 2) СВОБОДУ СЛОВА оно под- } \\
\text { вергло ограничениям, запретив } \\
\text { совсем говорить о борьбе и вра- } \\
\text { жде классов (напр., капитали- } \\
\text { стов и рабочих), запретив гово- } \\
\text { рить против правительства, за- } \\
\text { претив заикаться о неповинове- } \\
\text { нии властям, делать «противо- } \\
\text { прави-тельственные возгласы». } \\
\text { Виновные подлежат аресту до } 1 \\
\text { месяца. }\end{array}$ \\
\hline
\end{tabular}

\footnotetext{
${ }^{1}$ Датируется по содержанию документа.
} 
3) СВОБОДУ СОЮЗОВ. Он без всякого разрешения правительства покрыл всю Россию сетью рабочих союзов, которые имели целью отстаивать интересы рабочего класса в борьбе с капиталом.

4) СВОБОДУ ПЕЧАТИ. Наборщики отказались набирать книги и газеты, которые хозяева будут представлять на рассмотрение и разрешение правительственных цензоров. Рабочие в столицах начали вооруженной рукой захватывать типографии, чтобы печатать в них без всякого позволения свои рабочие газеты. В России стали «самовольно» издаваться социал-демократические издания «Начало», «Новая Жизнь», «Московская газета», «Борьба» и т д.). Печать стала по истине свободной.

5) СВОБОДУ СТАЧЕК. Вся жизнь русского пролетариата за последние годы была одной непрерывной стачкой и правительство не смело никого из стачечников предать суду, хотя в шкафу у него и стоял закон, карающий за участие в стачках.
3) СВОБОДУ СОЮЗОВ правительство сочло нужным пообещать после того, как она была взята пролетариатом.

4) СВОБОДУ ПЕЧАТИ правительство не решилось обещать даже в широковещательном Манифесте 17 октября, но за то ее не раз сулил граф Витте.

5) СВОБОДУ СТАЧЕК правительство не посмело даже упомянуть в Манифесте 17 октября, хотя она задолго до этого манифеста вошла в жизнь.
3) СВОБОДУ СОЮЗОВ правительство пытается теперь стеснить законом. Оно намеренно истребить союзы, которые открыто выступают против правительства, или составляются железнодорожниками и чиновниками, или соединяются между собой для достижения общих целей (напр., бюро профессиональных союзов или союз союзов). Участие в рабочих союзах будет караться тюрьмой до 4 лет.

4) СВОБОДУ ПЕЧАТИ, действительно взятая с бою пролетариатом, обречена правительством на уничто-жение законом 23 ноября. По этому закону запрещено возбуждать в печати к устройству или продолжению стачек, к забастовкам на железных дорогах, телеграфе, телефоне или вообще в таком предприятии, прекращение деятельности которого угрожает безопасности государства или создает возможность общественного бедствия. Этим законом запрещено газетам убеждать чиновников и учащихся в необходимости забастовать, запрещено приглашать устраивать манифестации, запрещено печатать неблагоприятные отзывы о должностных лицах и правительственных учреждениях, оскорблять в печати войска или воинские части. За все это обещано тюремное заключение от 2 месяцев до 1 г. 4 мec.

5) СВОБОДУ СТАЧЕК, которую пролетариат добыл для себя ценою тяжелой борьбы правительство нагло хочет отнять законом 20 ноября: этим законом совершенно запрещено устраивать стачки в казенных предприятиях (напр., на каз[енных] завод[ax]) или в предприятиях, имеющих государственное или общественное значение (напр., на жел[езных] дорогах, телеграфах, телефонах, электрических станциях, водопроводах). Остальные стачки дозволены если 
6) НЕПРИКОСНОВЕННОСТЬ ЛИЧНОСТИ. Рабочие Петербурга не давали арестовать тех из своих товарищей, которых хотело захватить правительство: они охраняли и отбивали их вооруженными толпами.
6) НЕПРИКОСНОВЕННОСТЬ ЛИЧНОСТИ правительством тоже обещана в Манифесте 17 октября. они идут «мирно», если же рабочие прибегают к угрозам, насилию или бойкоту, они подлежат каре. Наказания за стачки доходят до 1 г. 4 мес. тюрьмы.

\section{6) НЕПРИКОСНОВЕННОСТЬ} ЛИЧНОСТИ правительство нагло и грубо нарушает на каждом шагу: об этом говорит арест руководителей почтовотелеграфного союза, членов крестьянского союза, председателя и членов Совета рабочих депутатов в Петербурге и целый ряд подобных же фактов в других местах России, не исключая и Перми. Правительство объявило значительную часть России на положении об усиленной охране и военном положении. Кроме того, оно предоставило простым губернаторам неслыханное право объявлять на положении об усиленной охране и даже военном положении те губернии, где начались почтово-телеграфные и железнодорожные забастовки. Между тем, при этих порядках не может быть и речи о неприкосно-венности личности: всякого можно обыскать, арестовать, выслать, судить военным судом, казнить...

Вот приобретения пролетариата в его революционной борьбе, вот лживые посулы и обещания правительства, не имеющие другой цели, как убаюкать восставший народ обещанием призрачных прав, вот те законы, которыми правительство награждает нас теперь. Все эти законы проведены одной только самодержавной царевой властью. И закон о стачках, и закон о собраниях, и закон о печати появились в виде Высочайших царевых указов. Вот вам и царское обещание, данное в манифесте 17 октября: «Непреклонная наша воля установит, как незыблемое правило, чтобы никакой закон не мог восприять силу без одобрения Государственной Думы».

Всякий, кто не впал еще в политическое слабоумие, познакомившись с «характерными» законами правительства, должен понять, что пора перестать верить лживым его обещаниям. Рабочий класс не отдаст правительству тех свобод, которые он добыл путем тяжелой борьбы, которые запечатлел своей кровью. Другие же слои населения, которые до сих пор, по старой привычке, еще верили в благожелательность царского сердца, в твердую решимость царя «даровать» права народу, в графа Витте - должны теперь понять, как глупо было верить и ждать. Пора бросить всякую дурацкую веру. Надеяться можно только на силу и мощь революционного пролетариата.

Никто не даст нам избавленья

Ни царь, ни Бог и не герой.

Добьемся мы освобожденья

Своею собственной рукой ${ }^{1}$.

Итак, вперед, революционный рабочий класс, на борьбу за окончательное освобождение России.

\footnotetext{
${ }^{1}$ Слова песни «Интернационал» (автор текста Э. Потье, русский перевод А. Коц).
} 
Вперед, граждане, в ряды пролетариата, в ряды руководящей его революционным движением Российской Социал-Демократической Рабочей Партии.

ДОЛОЙ САМОДЕРЖАВИЕ.

ДА ЗДРАВСТВУЕТ ДЕМОКРАТИЧЕСКАЯ РЕСПУБЛИКА И ВООРУЖЕННОЕ ВОССТАНИЕ, КОТОРЫМ МЫ ЕЁ ДОБЬЕМСЯ.

ПЕРМСКИЙ КОМИТЕТ РСДРП

\title{
№ 10 \\ Листовка Прикамской группы РСДРП о требовании созыва Учредительного Собрания на ос- нове всеобщего прямого равного и тайного избирательного права
}

Февраль 1906 г.

\author{
РОССИЙСКАЯ СОЦИАЛ-ДЕМОКР[АТИЧЕСКАЯ] РАБОЧАЯ ПАРТИЯ \\ Пролетарии всех стран, соединяйтесь!
}

Товарищи! Самодержавное правительство, под [напором] растущего народного волнения, с каждым днем принуждено идти на новые и новые уступки. Первая уступка - Государственная Дума [от 6] августа удовлетворила только дворян и капиталистов, которым только и дана была она. Остальная же часть русского общества, главным образом рабочий класс, которому не дано было право участвовать в выборах в Государственную Думу, продолжала волноваться и требовала созыва Всероссийского Учредительного Собрания, на основе всеобщего, равного, прямого и тайного избирательного права, для всех граждан достигших 20-летнего возраста без различия пола национальности и вероисповедания. Всеобщая забастовка в октябре заставила правительство издать Манифест 17 октября, при котором Дума становится уже не законосовещательным, а законодательным учреждением. Теперь ни один закон не может быть издан без одобрения Государственной Думы. 11 декабря по[ступило] новое положение о выборах в Государственную Думу. Теперь участвовать в выборах могут все достигшие 25-летнего возраста обладающие недвижимым имуществом, платящие налог, снимающие на свое имя квартиру, не менее года получающие жалование от государства, а также рабочие тех фабрик и заводов, где их не менее 50 человек. Но опять такое избирательное право не всеобщее, некоторая часть русского общества, в том числе рабочие мелких фабрик и мастерских, почему-то опять отстранены от участия в выборах, а так же и женщины. Далее выборы производятся по сословиям и при том с таким расчетом, что выборщиков от рабочих производится совсем ничтожное количество по отношению к числу выборщиков от других сословий. Так, например, в Петербургской губ[ернии] на 207 выборщиков не рабочих приходится только 24 выборщика рабочих в других губ[ерниях] число выборщиков ничтожно - 4, 3, 2, 1; а в [15] губ[ерниях] рабочие совсем не принимают участия в выборах. При таких условиях рабочим вряд ли удастся привести хоть одного депутата в Думу. Ко всему этому, выборы производятся двухстепенной и трехстепенной подачей голосов. Рабочие и крестьяне выбирают сначала уполномоченных, те выбирают выборщиков и наконец уже на общих избирательных собраниях выбираются депутаты в Думу ${ }^{1}$ Что же получается после такого просеиванья? Очевидно, в Думу попадут только капиталисты, попы м кулаки мироеды; рабочих опять только подразнят призраком избирательного права. Если рабочие согласятся участвовать в выборах в эту Думу и дадут ей собраться, то этим самым они отдают себя в руки своих врагов - капиталистов, которые без сомнения будут издавать законы только в свою пользу. Правда, капиталисты всеми силами стараются уверить рабочих, что они будут защищать интересы рабочих и постараются на будущее [время ввести] всеобщее, равное, прямое и тайное избирательное право. Поэтому они и советуют рабочим [идти с ними] в Думу. Так ли это, товарищи? Можем ли мы надеяться, что капиталисты, наши [озаботились] о наших интересах? Никогда этого не было и никогда не будет.

\footnotetext{
${ }^{1}$ Согласно новому закону, учреждались 4 избирательные курии (землевладельческая, городская, крестьянская и рабочая), исход выборов определялся соотношением выборщиков от курий в губернских собраниях. В землевладельческой курии один выборщик приходился на 2 тыс. землевладельцев, в городской — на 4 тыс. горожан, в крестьянской - на 30 тыс. крестьян и казаков, в рабочей - на 90 тыс. рабочих. Таким образом, один голос землевладельца приравнивался к 3 голосам горожан, 15 голосам крестьян и 45 голосам рабочих.
} 
Капиталистов не много; сами они своими силами могут добиться не многого; поэтому они всегда стараются опереться на силу рабочих, привлечь их разными обещаниями на свою сторону.

Достигнув же цели и добившись с помощью рабочих власти, они не только не исполнят данных обещаний, но наоборот с новой силой начнут притеснять рабочих.

Нет, товарищи, не дадим себя обмануть!

Не допустим, чтобы капиталисты пользовались плодами нашей борьбы. Не дадим собраться Думе.

Будем добиваться созыва Учредительного Собрания на основе всеобщего прямого равного и тайного избирательного права. Уже много добился рабочий класс в России, еще одно усилие и он одержит полную победу.

$$
\text { Долой Думу! }
$$

Да здравствует Учредительное Собрание!

Да здравствует Рос[сийская] соц[иал]-демо[кратическая] рабочая партия!

Февраль 1906 г.

\section{ПРИКАМСКАЯ ГРУППА}

Издано 5000 экземпляров.

Как волны бурливыя моря

Поднялся весь русский народ,

И к свету, к желанной свободе

Он ринулся смело вперед!

Борцов проливается кровь

Страдают собратья по тюрьмам

И попраны мир и любовь...

Дружней же на подвиг великий

Все граждане русской земли

За правду и правое дело

И наши собратья легли!

Дружней от полей и заводов,

К тому нас отчизна зовет:

Чтоб был и свободен и славен

Наш русский - страдалец народ!

Дружней быть может придется

Нам многим погибнуть в бою

За то же пусть дети увидят

Свободной отчизну свою! ${ }^{1}$

№ 11

Листовка Прикамской группы РСДРП «К учащейся молодежи»

с призывом присоединиться к революционной борьбе пролетариата

Mapm 1906 2.

\section{К УЧАЩЕЙСЯ МОЛОДЕЖИ}

Наступает годовщина нашей забастовки, нашего первого пробуждения от нездоровой школьной спячки. Волна событий всколыхнула русскую жизнь и прежние неясные стремления к свету, правде и деятельности вылились в твердые, определенные требования. 9 января истекшего года выдвинуло на сцену новые, творческие силы, и знаменательный день указал обществу не только пути к лучшему будущему, но и грозного борца за освобождение родины; обескураженное правительство начало сдаваться. Брожение не могло не всколыхнуть школу. Мертвая казарменная обстановка, затхлая атмосфера, циркуляры и предписания давили молодежь, и из педагогов - «человечков в футля-

\footnotetext{
${ }^{1}$ Авторство стихов установить не удалось.
} 
ре» «живых дробей». Юные силы, не находят лучшего приложения, гибли в чаду винных паров и разврата. Обидное равнодушие родителей, ушедших в свои раковины, еще более душило нас и вот, когда шторм политической бури разразился над государством, школа - этот барометр общества, отозвалась на совершающихся в стране события. Крик негодования и протеста объединил учащуюся молодежь. Царизм, не видя, что барометр общественного мнения зловеще понижается, ответил зверским избиением молодежи. Вспомните, товарищи, как взволновали нас курские события! ${ }^{1}$

Мы, до сих пор безучастные зрители дикой оргии «черных сотен», решили наконец ответить безумцам. Мы твердо заявили этим диким зверям «да и мы с ними», и нас давит та же слепая и «мрачная сила». Что же ответило нам начальство? Как отозвалось на это движение общества? «Они» испугались и молчали. Только уже впоследствии родители-обыватели испугались своей заячьей трусливости. Созвали два собрания, вынесли резолюцию и успокоились. Взволнованное на время болото опять заснуло. Но молодежь, видя свои силы, не могла помириться с благосклонными пожеланиями. Когда русские граждане борются за свою и нашу свободу, когда по России льется кровь, мы не станем заниматься бесполезной и мертвой наукой. Родители, на которых уже сказалось освободительное движение, заговорили. Реальное 2 было закрыто на время, был образован комитет для борьбы с рутиной школы.

Товарищи, что дала нам забастовка, что дал нам истекший год. Реальных фактов мы не видали. Правда, стали смотреть сквозь пальцы на «проступки». Но и только. Коренных изменений, которых мы добивались, нет и нет. Да и возможны ли они сейчас? В полицейском, бесправном государстве казарменные школы, не так ли? Следовательно, наша борьба за свои интересы необходимо должна вылиться в борьбу политическую. Конечно, смешна бы показалась претензия учащихся перекраивать общественный строй. Но далеко не смешны грозные движения угнетенных и бесправных масс. Революция идет, и от старого строя она не оставит камня на камне. Передовой застрельщик и вождь её, могучий, организованный пролетариат уже заставил «благочестивейшего» самодержца с братией с пеной у рта уступить свои позиции израненному, но грозному борцу. Но враг не сломлен. Он хитер и коварен. Пока он не добит, нет места свободной России. В наше время не может быть колебаний, как вести себя. Мы должны примкнуть к революционной армии. Главная сила и мощь её - организованный и сознательный пролетариат, глубоко революционный по своему положению. К нему! В его могучую среду несите вы живое слово, организуйте его! Еще много темных и не сознательных элементов в нем. Укажите им дорогу! Сплотите их! И поверьте, на своих могучих плечах рабочий класс вынесет главную тяжесть революции и заставит покориться абсолютизм!

Вы скажете: «Мы не знаем, как взяться за дело?»

Учитесь этому, у вас надежный руководитель - РСДРП. Под её руководством и в её рядах вы сломите тиранов и добьетесь свободного государства и свободной школы!

Д здравствует революционный пролетариат!

Да здравствует красное знамя С[оциал]-Д[емократ]ии!

ГРУППА УЧАЩИХСЯ

Типография Прикамской группы РСДРП

Март 1906 г.

\footnotetext{
${ }^{1} 12$ февраля 1905 г. в Курске молодёжь организовала уличную демонстрацию с требованиями отстранить от преподавания и руководства учебными заведениями отдельных реакционеров, учащиеся духовной и учительской семинарии, гимназисты подверглись разгону и избиениям со стороны полиции и черносотенцев. Неоправданная жестокость со стороны полиции вызвала негодование у общественности и всероссийский резонанс (см.: Евдокимова А. Г. Социальный протест различных слоёв населения Курской губернии в условиях революции 1905 года // Изв. Юго-Западного гос. ун-та. Сер.: История и право. 2016. № 3 (20). C. 182-187. URL: https://swsu.ru/izvestiya/serieshistory/history_pravo/3_2016.pdf).

${ }^{2}$ Сарапульское (Алексеевское) реальное училище открыто 11 февраля 1873 г. для подготовки квалифицированных специалистов технического профиля. В учебном процессе, помимо основных предметов, значительное место уделялось графическим дисциплинам: рисованию, черчению, строительному искусству.
} 


\section{СПИСОК ИСТОЧНИКОВ И ЛИТЕРАТУРЫ}

1. Андронов С. А. Большевистская печать в трёх революциях. М.: Политиздат, 1978. 343 с.

2. Вахрушев A. А. Вятская печать в годы первой русской революции // Вестн. Удм. ун-та. Сер.: История и филология. 2013. Вып. 3. С. 37-45.

3. Иерусалимский Ю. Ю. Нелегальная печать большевиков Верхнего Поволжья в Первой российской революции (1905-1907 гг.): автореф. дис. ... канд. ист. наук. М.: [б. и.], 1984. 25 с.

4. Иерусалимский Ю. Ю. Листовки революционных организаций Центрального промышленного района в период первой российской революции 1905-1907 гг. Ярославль: Ярославский университет, 1997. 182 с.

5. Иерусалимский Ю. Ю. Социал-демократические листовки во время отступления первой российской революции в Верхнем Поволжье. Январь 1906 г. — 3 июня 1907 г. // Вестник архивиста. 2018. № 1. С. $219-235$.

6. История Удмуртии. Конец XV - начало XX века. Ижевск: УИИЯЛ, 2004. 549 с.

7. Кожевников В. П. Пропаганда и агитация большевиков в дооктябрьский период. М.: Политиздат, 1983.96 с.

8. Листовки петербургских большевиков (1902-1917). В 3 т. Т. 1: 1902-1907. М.: Госполитиздат, 1939. 566 с.

9. Листовки московских большевиков в период первой русской революции. М.: Госполитиздат, 1955. 592 с.

10. Листовки большевиков Среднего Поволжья к крестьянам в период революции 1905-1907 гг. (Учёные записки. Т. XIV). Ульяновск, 1958. 131 с.

11. Листовки и прокламации Самарского комитета РСДРП(б) 1902-1917. Куйбышев, 1959. 655 с.

12. Лицарев М. Ю. Пропагандистская и агитационная деятельность в Вятской губернии в период Первой российской революции 1905-1907 гг. // Вестн. Вят. гос. гуманитар. ун-та. 2014. № 4. С. 48-52.

13. Масютин $A$. C. Подпольная издательская деятельность социалистов-революционеров Вятской губернии (1904-1914 гг.) // Вестн. Вят. гос. гуманитар. ун-та. 2017. № 11. С. 53-59.

14. Очерки истории Удмуртской организации КПСС. Ижевск: Издательство «Удмуртия», 1968. 488 с.

15. Попов В. К. Большевистская печать Удмуртии в годы первой русской революции (1905-1907 гг.) // Записки Удмуртского научно-исследовательского института истории, экономики, литературы и языка. Вып. 18. Ижевск, 1957. С. 30-51.

16. Портянкин И. А. Большевистская печать в годы первой русской революции. М.: Госполитиздат, 1956.127 с.

17. Петропавловский Е. С. Листовки как источник при изучении истории КПСС. М.: Высшая школа, 1966.83 с.

18. Революция 1905-1907 гг. в Прикамье: документы и материалы / сост.: Е. Н. Лукьянова, Н. А. Аликина. Молотов, 1955. $328 \mathrm{c.}$

19. Революция 1905-1907 гг. в Удмуртии: материалы и документы / отв. ред. А. Ф. Завойских. Ижевск: Удмурт. кн. изд-во, 1956. $140 \mathrm{c.}$

20.Рябухин Е. И., Садаков М. А. Краткий очерк истории социал-демократических организаций Удмуртии. Ижевск: Удмурт. кн. изд-во, 1963. 99 с.

21. Хрестоматия по истории Удмуртии. Т. 1. Документы и материалы. 1136-1917. Ижевск, 2007. 816 с.

22. Центральный государственный архив Удмуртской Республики (ЦГА УР). Фонд 216. Помощник начальника Вятского жандармского управления по Глазовскому уезду (ЦГА УР, ф. 216, оп. 1, д. 1, л. 88-90).

23. Шелохаев В. В. Многопартийность, «висевшая в воздухе» // Полис. 1993. № 6. С. 166-171.

Поступила в редакцию 15.12.2019

Воронцов Владимир Степанович, кандидат исторических наук, старший научный сотрудник

ФГБУН «Удмуртский институт истории, языка и литературы» УдмФИЦ УрО РАН

426004, Россия, г. Ижевск, ул. Ломоносова, 4

E-mail: vvorontsov@rambler.ru

\section{V.S. Vorontsov \\ LEAFLETS OF THE KAMA AND PERM SOCIAL-DEMOCRATIC ORGANIZATIONS OF THE PERIOD OF THE FIRST RUSSIAN REVOLUTION OF 1905-1907}

DOI: $10.35634 / 2412-9534-2020-30-4-695-717$

The presented publication includes an introductory article and campaign materials from the period of the first Russian revolution, published by the Kama and Perm social-democratic organizations. The published documents were found during the analysis of a private house in Sarapul and transferred for storage to the Udmurt Institute of history, language and literature of the Udmurt Federal Research Center UB RAS. The find includes 10 leaflets and a flying leaf published by printing, as well as handwritten notes (separate pages) with text about the actions of workers during the armed uprising against the police and army units. The leaflets are written in plain, understandable language, with a pronounced focus on target groups (urban residents, workers, soldiers, recruits, students). They contain information explaining the 
actions of the government and revolutionaries, call for an armed uprising, demand the convocation of the all-Russian Constituent Assembly and the boycott of elections to the State Duma, and tell about significant regional events. Leaflets of regional social-democratic organizations are an important source for studying the history of the first Russian revolution of $1905-1907$.

Keywords: the first Russian revolution of 1905-1907, RSDLP, Perm and Kama Social-Democrats, propaganda materials.

\section{REFERENCES}

1. Andronov $S$. A. Bol'shevistskaya pechat' v trekh revolyutsiyakh [The Bolshevik press in three revolutions]. Moscow, "Politizdat" Publ., 1978, 343 p. (In Russian).

2. Vakhrushev A. A. Vyatskaya pechat' v gody pervoi russkoi revolyutsii [Vyatka press during the years of the first Russian revolution]. Vestnik Udmurtskogo universiteta. Seriya Istoriya i filologiya [Bulletin of the Udmurt University. Series History and Philology], 2013, no. 3, pp. 37-45 (In Russian).

3. Ierusalimskii Yu. Yu. Nelegal'naya pechat' bol'shevikov Verkhnego Povolzh'ya v Pervoi rossiiskoi revolyutsii (1905-1907 gg.) [Illegal press of the Bolsheviks of the Upper Volga region in the First Russian Revolution (19051907)]. Avtoref. ... dis. kand. ist. nauk. Moscow, [n. a.], 1984. 25 p. (In Russian).

4. Ierusalimskii Yu. Yu. Listovki revolyutsionnykh organizatsii Tsentral'nogo promyshlennogo raiona v period pervoi rossiiskoi revolyutsii 1905-1907 gg. [Leaflets of the revolutionary organizations of the Central Industrial Region during the first Russian revolution of 1905-1907]. Yaroslavl, Yaroslavl University Press, 1997, 182 p. (In Russian).

5. Ierusalimskii Yu. Yu. Sotsial-demokraticheskie listovki vo vremya otstupleniya pervoi rossiiskoi revolyutsii $\mathrm{v}$ Verkhnem Povolzh'e. Yanvar' 1906 g. - 3 iyunya 1907 g. [Social Democratic leaflets during the retreat of the first Russian revolution in the Upper Volga region. January 1906 - June 3, 1907]. Vestnik arkhivista [Archivist's newspaper], 2018, no. 1, pp. 219-235. (In Russian).

6. Istoriya Udmurtii. Konets XV - nachalo XX veka [History of Udmurtia. Late 15th - early 20th century]. Izhevsk, Ed. of the Udmurt Institute of History, Language and Literature, 2004, 549 p. (In Russian).

7. Kozhevnikov V. P. Propaganda i agitatsiya bol'shevikov v dooktyabr'skii period [Propaganda and agitation of the Bolsheviks in the pre-October period]. Moscow, "Politizdat" Publ., 1983, 96 p. (In Russian).

8. Listovki peterburgskikh bol'shevikov (1902-1917) [Leaflets of the St. Petersburg Bolsheviks (1902-1917)]. V 3 t. T. 1. 1902-1907. Moscow, "Gospolitizdat” Publ., 1939, 566 p. (In Russian).

9. Listovki moskovskikh bol'shevikov v period pervoi russkoi revolyutsii [Leaflets of the Moscow Bolsheviks during the first Russian revolution]. Moscow, "Gospolitizdat" Publ., 1955, 592 p. (In Russian).

10. Listovki bol'shevikov Srednego Povolzh'ya k krest'yanam v period revolyutsii 1905-1907 gg. [Leaflets of the Bolsheviks of the Middle Volga to the peasants during the revolution of 1905-1907] (Uchenye zapiski. Tom XIV). Uliyanovsk, 1958, 131 p. (In Russian).

11. Listovki i proklamatsii Samarskogo komiteta RSDRP(b) 1902-1917 [Leaflets and proclamations of the Samara Committee of the RSDLP(b) 1902-1917]. Kuibyshev, 1959, 655 p. (In Russian).

12. Litsarev M. Yu. Propagandistskaya i agitatsionnaya deyatel'nost' v Vyatskoi gubernii v period Pervoi rossiiskoi revolyutsii 1905-1907 gg. [Advocacy and campaigning in the Vyatka province during the First Russian Revolution of 1905-1907]. Vestnik Vyatskogo gosudarstvennogo gumanitarnogo universiteta [Bulletin of Vyatka State Humanitarian University], 2014, no. 4, pp. 48-52. (In Russian).

13. Masyutin A. S. Podpol'naya izdatel'skaya deyatel'nost' sotsialistov-revolyutsionerov Vyatskoi gubernii (1904-1914 gg.) [Underground Publishing Activities of the Socialist Revolutionaries of the Vyatka Province (1904-1914)]. Vestnik Vyatskogo gosudarstvennogo gumanitarnogo universiteta [Bulletin of Vyatka State Humanitarian University], 2017, no. 11, pp. 53-59. (In Russian).

14. Ocherki istorii Udmurtskoi organizatsii KPSS [Essays on the history of the Udmurt organization of the CPSU]. Izhevsk, "Udmurtiya” Publ., 1968, 488 p. (In Russian).

15. Popov V. K. Bol'shevistskaya pechat'Udmurtii v gody pervoi russkoi revolyutsii (1905-1907 gg.) [The Bolshevik press of Udmurtia during the years of the first Russian revolution (1905-1907)]. Zapiski Udmurtskogo nauchnoissledovatel'skogo instituta istorii, ekonomiki, literatury i yazyka [Notes of the Udmurt Research Institute of History, Economics, Literature and Language], issue 18. Izhevsk, 1957, pp. 30-51. (In Russian).

16. Portyankin I. A. Bol'shevistskaya pechat' v gody pervoi russkoi revolyutsii [The Bolshevik press during the years of the first Russian revolution]. Moscow, "Gospolitizdat" Publ., 1956, 127 p. (In Russian).

17. Petropavlovskii E. S. Listovki kak istochnik pri izuchenii istorii KPSS [Leaflets as a source in the study of the history of the CPSU]. Moscow, "Higher school" Publ., 1966, 83 p. (In Russian).

18. Revolyutsiya 1905-1907 gg. v Prikam'e: Dokumenty i materialy [The revolution of 1905-1907 in Prikamye: Documents and materials]. Sost.: E. N. Luk'yanova, N. A. Alikina. Molotov, 1955, 328 p. (In Russian).

19. Revolyutsiya 1905-1907 gg. v Udmurtii: Materialy i dokumenty [The revolution of 1905-1907 in Udmurtia: Materials and documents]. Otv. red. Zavoiskikh A. F. Izhevsk, "Udmurtskoe knizhnoe izdatel'stvo" Publ., 1956,140 p. (In Russian). 
20. Ryabukhin E. I., Sadakov M. A. Kratkii ocherk istorii sotsial-demokraticheskikh organizatsii Udmurtii [A brief outline of the history of the social democratic organizations of Udmurtia]. Izhevsk, "Udmurtskoe knizhnoe izdatel'stvo" Publ., 1963, 99 p. (In Russian).

21. Khrestomatiya po istorii Udmurtii. T. 1. Dokumenty i materialy. 1136-1917 [A reader on the history of Udmurtia]. Izhevsk, 2007, 816 p. (In Russian).

22. Tsentral'nyi gosudarstvennyi arkhiv Udmurtskoi Respubliki (TsGA UR) [Central State Archive of the Udmurt Republic]. Fond 216. Pomoshchnik nachal'nika Vyatskogo zhandarmskogo upravleniya po Glazovskomu uezdu [Assistant to the Head of the Vyatka Gendarme Office for Glazovsky Uyezd]. (in Russian, unpublished).

23. Shelokhaev V. V. Mnogopartiinost', "visevshaya v vozdukhe" [A multi-party system, "hanging in the air"]. Polis [Policy], 1993, no. 6, pp. 166-171. (In Russian).

Vorontsov V. S., Candidate of History, Senior researcher Udmurt Institute of History, Language and Literature UdmFIC Ural Branch of RAS Lomonosova st., 4, Izhevsk, Russia, 426004

E-mail:vvorontsov@rambler.ru 